\title{
The Efficacy of Medical Expulsion Therapy in Distal Ureteric Calculi
}

\author{
Adhikari Dhurba Bahadur ${ }^{1}$, Shrestha David ${ }^{1 *}$, Poudel Suresh Raj ${ }^{1}$ \\ ${ }^{1}$ Department of Surgery, Pokhara Academy of Health Sciences, Western Regional Hospital, Pokhara
}

\section{*Corresponding Author}

Dr. David Shrestha

General Surgeon,

Department of Surgery,

Pokhara Academy of Health Sciences, Western Regional Hospital, Pokhara

Email: pokhrelidavid@yahoo.com

Article received : February 12, 2018

Article accepted : February 25, 2018

\begin{abstract}
Objective: To evaluate the efficacy of tamsulosin in the treatment of distal ureteric calculi. Materials and Methods: Forty patients, who meet the inclusion criteria, were selected for the prospective study. All these patients received tamsulosin $0.4 \mathrm{mg}$ once before bed time for fourteen days to observe the effectiveness, side effects and stone expulsion rate. Results: The average time of stone expulsion was $8.03 \pm 2.80$ days. The successful medical expulsion was seen in $82.50 \%$. About $7.5 \%$ complained of dizziness and headache, $2.5 \%$ complained of fatigue and postural hypotension. Conclusion: The use of tamsulosin was safe, effective and was associated with fewer side effects. Successful stone expulsion rate was observed in in selected cases.
\end{abstract}

Keywords: Alpha blocker, tamsulosin, calculi

\section{INTRODUCTION}

Urinary tract calculi are one of the common urological conditions worldwide. The incidence of urinary tract calculi is increasing in the general population. It affects mostly the male population compared to females with incidence of $1-15 \% . .^{1,2}$ Most of these calculi will pass spontaneously, depending upon the size and location of the calculi. Various treatment modalities have been described for the ureteric calculi. However, choice of the treatment is largely based on the type, size and position of the calculi, along with anatomical considerations and need of the patients. ${ }^{3}$ To facilitate calculi expulsion and reduce post-operative complications, recent studies have recommended a medical expulsion therapy (MET). Alpha blockers and calcium channel blockers are the most commonly used drugs for MET.

The alpha adrenergic receptor is a $\mathrm{G}$ protein-coupled receptor associated with the heterotrimeric G-protein. The alpha adrenergic receptor is classified into alpha-1 and alpha-2. Alpha-1 consists of three highly homologous sub types, A, B and D, and alpha- 2 consist of A, $\mathrm{B}$ and $\mathrm{C}$ respectively. Alpha adrenergic receptors have several functions in common, but also individual effects. Specific action of the $\mathbf{q}_{1}$ receptor mainly is smooth muscle contraction. ${ }^{4}$ The alpha adrenergic receptors are numerous in the lower ureter, compared to the mid or upper ureter. ${ }^{5}$ The blockage of adrenergic receptors reduces basal tone, peristaltic activity and ureteric contraction.
We chose tamsulosin for this study, a selective alpha-1 antagonist. It inhibits basal smooth muscle tone, peristaltic frequency and amplitude leading to decrease in the intra-ureteric pressure, ureteric relaxation and increase in fluid transport along the ureter. ${ }^{4-6}$ The aim of this study is to evaluate the efficacy and safety of tamsulosin for the distal ureteric calculi.

\section{MATERIALS AND METHODS}

This prospective study was conducted in the Department of Surgery, Pokhara Academy of Health Sciences, Western Regional Hospital, Pokhara from June 2016 to June 2017. The study protocol was explained to all participants and consent was received prior to inclusion. Forty patients aging sixteen to fifty-eight years old were involved in this study with the diagnosis of distal ureteric calculi who met the inclusion criteria. Among this population, twenty-seven were males and thirteen were females. All patients were evaluated thoroughly by medical history, clinical examination, and complete laboratory and radiological investigations.

\section{Inclusion Criteria:}

- $\quad$ Age $\geq 16$ years old

- Distal ureteric calculi

- Single radio-opaque calculi 
- $\quad 5-10 \mathrm{~mm}$ in maximum diameter

Exclusion Criteria:

- $\quad$ Calculi size $>10 \mathrm{~mm}$

- Persistent renal pain

- Urinary tract infection

- Renal impairment

- Solitary kidney

- Patients with endoscopic or open ureteral surgical history

- Bilateral ureteral calculi or multiple unilateral calculi

- Moderate to severe hydronephrosis

- $\quad$ Pregnant women, patient with Diabetes Mellitus or peptic ulcer disease

- Hypersensitivity to alpha blockers

Initial diagnosis was made by ultrasonography (USG), followed by X-ray KUB and confirmed with CT Urography. Routine urine analysis and serum creatinine were within normal limits in all patients. Patients received daily dose of tamsulosin $0.4 \mathrm{mg}$ for 14 days or till spontaneous passage of calculi within 14 days. Patients were asked to take analgesic (NSAIDs) for moderate to severe pain if required and high fluid intake was advised with usual daily routine. During this time period, follow up was done twice on $7^{\text {th }}$ and $14^{\text {th }}$ day of treatment with urinalysis, serum creatinine, X-ray KUB and USG. Patients were suggested to discontinue the treatment after expulsion of calculi and to visit to outpatient department for confirmation. Expulsion of calculi was confirmed by USG. The medical expulsion therapy was deemed a failure if patients failed to pass calculi within 14 days, developed uncontrolled pain, urinary tract infection or fever, if there was increase in hydronephrosis, or if calculi required intervention. Data collection and statistical analysis were done using SPSS 22.0. The different study variables were analyzed using descriptive statistics.

\section{RESULTS}

Forty patients were included in this prospective study from June 2016 to June 2017, with age range of sixteen to fifty eight years, with mean age of $31.75 \pm 12.22$ years. Where twenty seven $(67.50 \%)$ were males and thirteen
$(32.50 \%)$ were females. The calculi were detected in right ureter in $60 \%$. Sizes of the calculi ranged between $6 \mathrm{~mm}$ to $10 \mathrm{~mm}$ with mean size of $8.07 \pm 1.60 \mathrm{~mm}$. The mean duration of calculi expulsion was $8.03 \pm 2.80$ days. Among forty patients, successful medical expulsion was seen in $82.50 \%$ and remaining $17.50 \%$ were unable to expel the calculi with 14 days of medical therapy. The failure group underwent invasive treatment.

Table 1. Patients demographic features and outcomes

\begin{tabular}{|c|c|c|}
\hline & Details & Study group \\
\hline 1. & $\mathrm{~N}$ & 40 \\
\hline 2. & Age in year $($ mean $\pm S D)$ & $31.75 \pm 12.22$ \\
\hline \multirow{3}{*}{3.} & Gender: & \\
\hline & Male & $27(67.50 \%)$ \\
\hline & Female & $13(32.50 \%)$ \\
\hline \multirow{3}{*}{4.} & Location of stone: & \\
\hline & Right & $24(60.00 \%)$ \\
\hline & Left & $16(40.00 \%)$ \\
\hline 5. & Stone size in $\mathrm{mm}($ mean $\pm \mathrm{SD})$ & $8.07 \pm 1.60$ \\
\hline 6. & $\begin{array}{l}\text { Duration of expulsion in } \\
\text { days (mean } \pm \mathrm{SD} \text { ) }\end{array}$ & $8.03 \pm 2.80$ \\
\hline 7. & Expulsion rate & $33 / 40(82.50 \%)$ \\
\hline 8. & Failure rate & $7 / 40(17.50 \%)$ \\
\hline 9. & Complications & $\begin{array}{l}\text { Dizziness } 3(7.5 \%) \text {, Headache } \\
3(7.5 \%) \text {, Fatigue } 1(2.5 \%), \\
\text { Postural Hypotension } 1(2.5 \%)\end{array}$ \\
\hline
\end{tabular}

In this study, common complications encountered were dizziness, headache, fatigue and postural hypotension. None of these side effects required withdrawal of the study medication or any definitive treatment.

\section{DISCUSSION}

Presence of ureteric calculi does not always require invasive or surgical intervention. It depends upon the size, location and the level of obstruction at initial presentation. Large number of patients passes calculi spontaneously with sufficient hydration only. According to American Urological Association (AUA) guidelines, about 98\% of ureteric calculi, size less than $5 \mathrm{~mm}$ will pass spontaneously without any medical therapy. ${ }^{7}$ About $35.2 \%$ to $61 \%$ of ureteric calculi sized less than $10 \mathrm{~mm}$, too, pass spontaneously. ${ }^{8-10}$

However, patients with calculi less than $10 \mathrm{~mm}$ without medical therapy might develop severe complications and lead to surgical intervention if waited for longer duration. It is known that the larger the calculi the lower the chance of spontaneous passage of calculi. ${ }^{10}$ Thus, medical treatment is probably most effective for calculi size of about 
$5-10 \mathrm{~mm}$. Medical therapy is found to be cost-effective and is justified before embarking upon surgical option. ${ }^{11}$ Various randomized trials confirm the efficacy of medical expulsion therapy and it helps in reducing the pain during calculi passage. We can conclude that overall rate of surgical intervention is reduced with medical treatment. ${ }^{12,13}$

In this study, the choice of medical expulsion therapy is "tamsulosin" - alpha blocker. The presence of alpha adrenergic receptors in the human ureter was first described in $1970 .{ }^{14}$ The mechanism of action of alpha blockers on the ureteral smooth muscle is increase in the expulsion rate of calculi and decrease in the time it takes for expulsion. This suggests that alpha adrenergic receptor antagonists ought to be the preferred for medical expulsion therapy for ureteric calculi. ${ }^{15}$ The goal of the MET is to accelerate calculi passage, avoid surgery and reduce analgesic requirement. Calculi in the ureter cause partial or complete obstruction which activates the alpha1 receptors, leading to increase in the contraction of ureteric smooth muscles and increase in the frequency of ureteral peristalsis. Blockage of alpha1 receptors decreases basal tone, prevents peristaltic amplitude and frequency, and lowers intraluminal pressure. At the same time, it increases the rate of fluid transport and the chances of calculi expulsion. ${ }^{16,18}$ In short, alpha1 antagonists cause ureteric relaxation distal to calculi, decrease in peristaltic movement and increase in fliud volume transport along the ureter. All this finally results in calculi expulsion. This is the basis of MET. Dellabella and colleagues ${ }^{16}$ have highlighted the efficacy of tamsulosin and have expressed that MET was associated with an increased calculi expulsion rate and a decreased time to calculi expulsion. ${ }^{16}$ Also, two randomized controlled studies by Al-Ansari and colleagues ${ }^{8}$ and Kaneko and colleagues ${ }^{17}$ validated the efficacy of tamsulosin for distal ureteral calculi without significant side effects.

Out of forty patients, seven $(17.50 \%)$ could not pass calculi after fourteen days treatment. In all of these patients, USG showed increase in hydronephrosis. The position of calculi in three patients changed to a more distal region in the ureter. In rest of the patients, no change was seen compared to the previous scan. Serum creatinine was within normal limits. Mild pain was present but was relieved with NSAIDs. After failure of MET, these patients underwent ureteroscopic lithotripsy (URSL). The mean size of the calculi in these seven patients was $9.14 \pm 0.69$ $\mathrm{mm}$.

Alpha1 antagonists have a crucial role in spontaneous painless elimination of the calculi. ${ }^{19}$ MET is a viable op- tion in selected population, where the role of immediate surgical calculi removal is less. In contrast, the minimal invasive surgery for ureteric calculi is accepted as gold standard. However, these techniques are not risk free, are quite expensive and are available mostly at tertiary centers. ${ }^{20}$

\section{CONCLUSION}

This study demonstrates the use of tamsulosin to be safe and effective, with few side effects and with increased calculi expulsion rate. MET can be used as an alternative treatment option for distal uretic calculi in selected cases. It can be beneficial for the patients who are unfit for the surgery, who do not want to go for the surgery or stay in hospital, and who cannot afford the surgical procedure.

Source of funding

NHS Nepal (Naulo Health Service), Pokhara, Nepal

Conflict of interest None

\section{REFERENCES}

1. Pak CY. Kidney stones. Lancet. 1998 Jun;351(9118):1797-01.

2. Smith RD, Shah M, Patel A. Recent advances in management of ureteral calculi. F1000 Med Rep. $2009 \mathrm{Jul} ; 1: 53$

3. Finlayson B, Ackermann D. Overview of surgical treatment of urolithiasis with special reference to lithotripsy. J Urol. 1989 Mar; 141(3 Pt 2):778-9.

4. Nakada SY. Tamsulosin: ureteric motility. BJU Int. 2008 May;101(9):1061-2.

5. Davenport K, Timoney AG, Keeley FX. A comparative in vitro study to determine the beneficial effect of calcium-channel and alpha(1)-adrenoceptor antagonism on human ureteric activity. BJU Int. 2006 Sept;98:651-5.

6. Davenport K, Timoney AG, Keeley FX. Effect of smooth muscle relaxant drugs on proximal human ureteric activity in vivo: a pilot study. Urol Res. 2007 Aug;35(4):207-13.

7. Segura JW, Preminger GM, Assimos DG, Dretler SP, Kahn RI, Lingeman JE, et al. Ureteral Stones Clinical Guidelines Panel summary report on the management of ureteral calculi. The American Urological Association .J Urol. 1997 Nov;158(5):1915- 
21.

8. Al-Ansari A, Al-Naimi A, Alobaidy A, Assadiq K, Azmi MD,Shokeir AA. Efficacy of tamsulosin in the management of lower ureteral stones: a randomized double-blind placebo-controlled study of 100 patients. Urology. 2010 Jan;75(1):4-7.

9. Abdel-Meguid TA, Tayib A, Al-Sayyad A. Tamsulosin to treat uncomplicated distal ureteral calculi: a double blind randomized placebo-controlled trial. Can J Urol. 2010 Jun;17(3):5178-83.

10. Agrawal M, Gupta M, Gupta A, Agrawal A, Sarkari A, Lavania P. Prospective randomized trial comparing efficacy of alfuzosin and tamsulosin inmanagement of lower ureteral stones. Urology. 2009 Apr;73(4):706-9

11. Bensalah K, Pearle M, Lotan Y. Cost-effectiveness of medical expulsive therapy using alpha-blockers for the treatment of distal ureteral stones. Euro Urology. 2008 Feb;53(2):411-8.

12. Cooper JT, Stack GM, Cooper TP. Intensive medical management of ureteral calculi. Urology. 2000 Oct;56(4):575-8.

13. Porpiglia F, Ghignone G, Fiori C, Fontana D, Scarpa RM. Nifedipine versus tamsulosin for the management of lower ureteral stones. J Urol. 2004 Aug;172(2):568-71.

14. Malin JM Jr, Deane RF, Boyarsky S. Characterisation of adrenergic receptors in human ureter. $\mathrm{Br} \mathrm{J}$
Urol. 1970 Jun;42:171-4.

15. Tzortzis V, Mamoulakis C, Rioja J, Gravas S, Michel MC, de la Rosette JJ. Medical expulsive therapy for distal ureteral stones. Drugs. 2009 April;69(6):677-92.

16. Dellabella M, Milanese G, Muzzonigro G. Efficacy of tamsulosin in the medical management of juxta vesical ureteral stones. J Urol. 2003 Dec;170(6 Pt 1):2202-5.

17. Kaneko T, Matsushima H, Morimoto H, Tsuzaka Y, Homma Y. Efficacy of low dose tamsulosin in medical expulsive therapy for ureteral stones in Japanese male patients: A randomized controlled study. Int J Urol. 2010 Feb;17:462-5.

18. Pickard R, Starr K, MacLennan G, Lam T, Thomas R, Burr $\mathrm{J}$, et al. Medical expulsive therapy in adults with ureteric colic: a multicentre,randomised, placebo-controlled trial. Lancet. 2015 Jul;386(9991):341-9.

19. Pricop C, Novac C, Negru D, ILie C, Pricop A, Tanase V. Can selective alpha blockers help the spontaneous passage of the stones located in the uretero bladder junction? Rev Med Chir Soc Med Nat. 2004 Jan;108(1):128-33.

20. Lotan Y, Gettman MT, Roehrborn CG, Cadeddu JA, Pearle MS. Management of ureteral calculi: A cost comparison and decision making analysis. J Urol. 2002 Apr;167(4):1621-9. 